文

献

紹 介

\begin{tabular}{|c|c|c|c|c|}
\hline B & $\begin{array}{l}56^{\circ} 6 \\
77^{\circ} 7\end{array}$ & $\begin{array}{l}21 \cdot 0 \\
23^{\circ} \cdot 5\end{array}$ & $\begin{array}{l}16^{\circ} 0 \\
18^{\circ} 0\end{array}$ & $\begin{array}{r}9.5 \\
10.0\end{array}$ \\
\hline C & $\begin{array}{l}75^{\circ} \\
86^{\circ} 0\end{array}$ & $\begin{array}{l}30^{\circ} 0 \\
38^{\circ} 0\end{array}$ & $\begin{array}{l}21^{\circ} 0 \\
23 \cdot 5\end{array}$ & $\begin{array}{l}14 \cdot 5 \\
14 \cdot 5\end{array}$ \\
\hline D & $91^{\circ} 7$ & $32^{\circ} 0$ & $28^{\circ} 0$ & $15^{\circ} 0$ \\
\hline
\end{tabular}

\begin{tabular}{c|c|c|c|c}
\hline $\mathrm{E}$ & 82.8 & 32.0 & $27 \cdot 0$ & $17 \cdot 0$ \\
\hline $\mathrm{F}$ & 89.2 & $36^{\circ} 0$ & $27^{\circ} 0$ & 15.0 \\
\hline $\mathrm{G}$ & 85.0 & 26.5 & $24^{\circ} 0$ & 15.5 \\
\hline
\end{tabular}

[丰上嗍郎了

\section{6. 蒸気発生裝置}

\subsection{7}

\section{[162]模型によるボイラ・ドラム における気水分離の㸴究}

[E. A. Farber, Transactions of the A.S. M.E. Vol. 73, No. 3, 1951-4, p. 247〜256, 戍 18] 高温高王のボイラ・ドラムに和ける父水分湤の作究を 低温低忹の模型で行うとき 水之空気至使うと条件7湋 って上い比較ができないの で, Freon 12を朋らると気

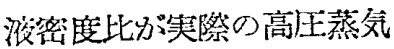
とその館和水の密度比と、同 一にできて，くわしい比較 梌討ができる，実験は第 1 戍の上らなけイクロンやス パイダーをドラム内部に設 けて钺水の分離の比輘を行

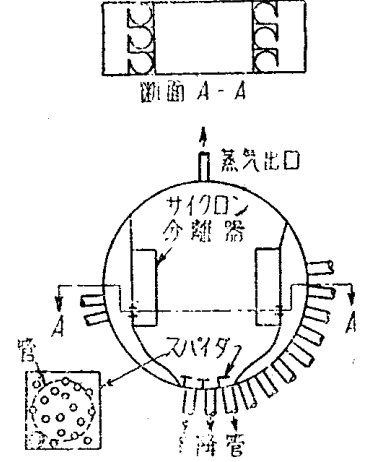

第 1 龱

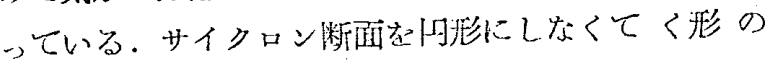

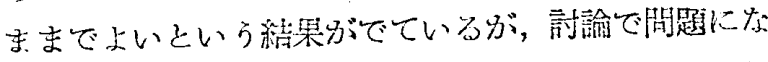

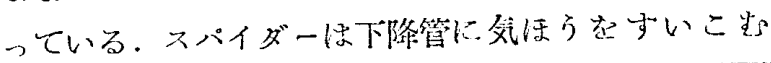

\section{8. 內 燃}

$621.43 .013 .9: 621.432 .3$

\section{[163] 4 衝程機䦎の排気行程の解析}

[Trans. A.S.M.E., April 1951, pp. 319 329] シリンダ内の排気行程打の忹力変化を次の敒定の下 にて算出している。すなわち(1)完全ガスの法則名简

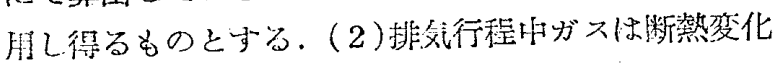
起行うむのとする.（3）排気老を通じての流れは定常

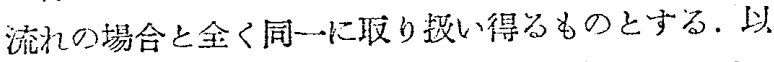
上の三つが主要な仮定で希り解航の藇楚となってい る。そしてこの結果に基いて排終りの上死点前 $20^{\circ}$

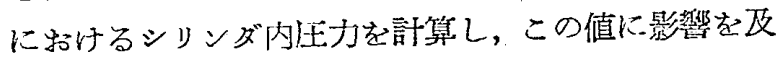
ぼす因子学明らかにし高性能発動機の設計に当ってこ れ等の因子をいかに故らべきかについて諭じている。
らずの生成を防ぐものでをる。蒸效に伴われる水分

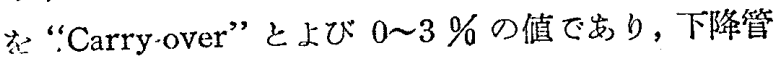
よび $0 \sim 20 \%$ の值でをる. Enterainment の定義が 蒸溜等の時も異なるから注意を要する. 測定方法とし て前者はオリフィス前後の生方々温度に上り，後者は

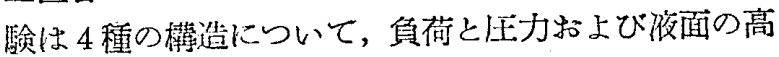
さを変えて行って夜る。与なわ占水面が高いと“Carry.over” は增加し “Entrainment”は減少する。次

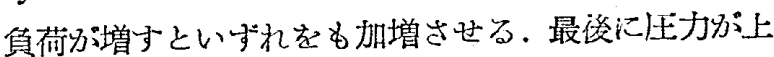

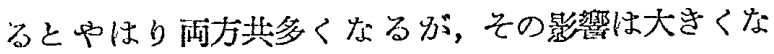
つくから分噍は困難となるが，分離力を大きくするた るこ之は忹力損失を大きくするし，をふれ出たりする ので制限がをる。な特 Freon 12 をつかったのは安俩 のためで女). (By courtesy of the A.S.M.E.)

[井伊谷鐗一]

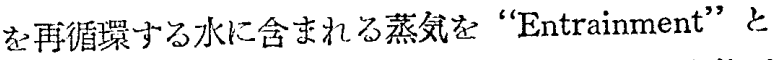

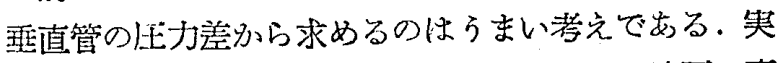
い。ボイラが高玨になる程蒸符と水の密度比は 1 に近 めにサイクロンの直径を小さくしたり, 速度を早くす

\title{
14. 圧縮機および逘風機
}

\subsubsection{1: 536.7 \\ [164]ガス压縮機一恒エントロピ圧縮の仕事}

[Joseph Joffe, Chem. Engg. Prog., Feb. 1951, Vol. 47, No. 2, p. 80 82] 理想ガスの恒エント 